\title{
Developmental State of Ethiopia: Reflections on the Costs of Viewing Economic Growth as a Governance Criterion
}

\author{
E. Bayeh \\ Ambo University \\ 19, Ambo, Ethiopia
}

\begin{abstract}
The paper examines the achievements and losses of the Ethiopian state following the introduction of the developmental state model. In his research, the author relies mostly on secondary sources, upon a thorough analysis of which he draws the following conclusion: Even though the developmental state model has led to a remarkable economic growth and made the country one of the fastest growing economies in the world, it has also caused several detrimental effects, including eroding the value of pluralism, compromising human rights, and consolidating a single-party authoritarian rule, which spurred a rampant corruption and intensified arbitrary intervention in the citizens' lives. The author suggests that economic growth and political transformation (democratization) should be valued equally and pursued side-by-side, which requires a genuinely patriotic, determined, and civic-minded leader.
\end{abstract}

Keywords: developmental state, authoritarian rule, Ethiopia, economic growth.

\section{The Notion of developmental state}

As there is an ongoing academic debate in regards to the concept of a "developmental state", it has no precise definition. So far, the literature in the area has been leaning more towards associating the term with the proactive role of the state in the country's economic development. A "developmental state" has been interpreted as a state which strives to achieve economic development by creating and regulating economic and political relations that can support sustainable industrialization [1]. Chalmers Johnson defines a developmental state as a state whose foremost and single-minded priority is economic development, defined in terms of growth, productivity, and competitiveness [2]. It is still described as "a state that is and seeks to be a strong player in the economy of a nation with a view to enhancing economic development" [3]. Hence, the concept is closely associated

(C) Bayeh E., 2019.

This work is licensed under a Creative Commons Attribution 4.0 International License https://creativecommons.org/licenses/by/4.0/ 
with the rapid advancement of industrialization and socio-economic transformation by way of strong governmental involvement in the economy. Developmental state was practiced in the $19^{\text {th }}$ century in Bismarck's Prussia and Meiji's Japan $[4 ; 5 ; 1]$. However, the most successful application of this concept resulting in a major socio-economic transformation took place in East Asian states between the 1960s and 1980s [6]. The introduction of the developmental state model brought about an astounding advance in the countries' economy and helped free them from abject poverty [7; 8]. Consequently, in academic circles the developmental state theory is used mainly to explain rapid industrialization and economic growth in East Asian states, often referred to as the Asian Tigers [4; 8; 9].

Ideologically, the developmental state is neither a capitalist nor a socialist system. Rather, it lies somewhere between a capitalist free market system and a centrally-planned command economy [4;8]. It borrows certain features from both of these diametrically opposite politico-economic arrangements. Although it maintains the capitalist economic ideas, the developmental state ideology encourages state intervention in the economy. As Johnson observes [5], a developmental state sets far-reaching social and economic goals. Some authors refer to it as to "an emphatic state, a hard state, relatively autonomous/independent, with a decidedly interventionist bent on seeking not only to regulate, guide, and shape, but also to monitor and control, the economy" [3]. However, adopting this system does not entail replacing the free market with the socialist system of planning and control [10]. Also, the developmental state is not identical to social democracy, which represents a blend of capitalist and socialist systems. In a developmental state economic progress is possible due to the state intervention in the economy, while in a social democracy state intervention presupposes guarantee of equality, social justice, and support to those at a disadvantageous position [10]. A developmental state is, thus, an interventionist state which is targeted at a fast economic development and plays a central role in it.

\section{Basic features of a developmental state}

As follows from literature on the subject, a developmental state is characterized by, but not limited to, the following basic features. Firstly, the overriding objective of a developmental state is achieving fast socio-economic development via the process of industrialization [4]. In so doing, it is necessary to make a certain change in the industrialization process: transition from an import-substituting system to an export-oriented economy [11]. East Asian states have achieved a rapid economic growth since technocratic bureaucrats made economic development their top priority and a long term goal [8].

Secondly, a developmental state needs a competent meritocratic autonomous bureaucracy. In a developmental state, public servants are authoritative professionals, who are protected from the influence of elected politicians $[3 ; 4 ; 12]$. They facilitate the socio-economic transformation of a state by enjoying a high degree of political autonomy $[4 ; 8 ; 13]$. Thus, while politicians "reign", the bu- 
reaucrats "rule" $[2 ; 13]$, in a developmental state, public servants hold the real power, therefore, meritocratic recruitment of such autonomous, capable bureaucrats plays a key part in East Asian states' impressive skyrocketing economic performance [14].

Thirdly, a developmental state, in its essence, is an interventionist state. The state actively intervenes in the economy by regulating, guiding and controlling it. Its intervention is single-mindedly aimed at promoting industrial growth and economic development [10].

Fourthly, a developmental state has a capitalist economic environment, where private sectors participate in macroeconomic planning $[2 ; 4]$. In other words, there is a public-private partnership. However, not all private sectors enjoy this partnership; rather, it is for selected strong enterprises that have the benefit of government subsidies. Besides, such a public-private cooperation does not result from voluntary compliance of private business elites; however, it is instigated by the coercive influence of bureaucrats [2].

The phenomenon of a developmental state is now spreading beyond East Asia, across various countries of the world. Many nations are rushing to adopt the East Asian model of development, with certain necessary alterations for some of them. Ethiopia, which is the main focus of the current research, is no exception to this trend. Concerns regarding whether the developmental state model is applicable in Ethiopia have taken center stage in the recent literature $[3 ; 15 ; 16]$. This article contributes to the existing discourse on the subject, as it examines the actual and potential gains and losses (a relatively less discussed aspect) following the adoption of the developmental state model in Ethiopia. The article follows up on the ideas set forth in the author's thesis, in particular that the Ethiopian government has been using economic growth as a guide for governance and that it has applied (and potentially will continue to apply) the developmental state model at the cost of some basic democratic precepts to ensure its long-lasting power. Accordingly, in his research the author tries to achieve the following main objectives:

- To investigate the patterns of change in the ideological orientation of Ethiopia during the last three successive regimes;

- To reveal actual and potential positive effects brought about by the developmental state model in Ethiopia;

- To examine actual and potential adverse effects brought about by the developmental state model in Ethiopia.

The study uses a qualitative approach, which attempts to interpret phenomena in terms of the meanings people attach to them. Qualitative research involves analyzing data, suggesting an interpretation and arriving at conclusions about the data analyzed [17]. The article offers qualitative interpretation and analysis of the secondary data, collected through a thorough study of books, journal articles, reports, and credible internet sources. 


\section{Results and discussion}

Patterns of Change in the Ideological Orientation of Ethiopia. Historically, Ethiopia has experienced various forms of politico-economic orientation during different regimes. Different ideological tendencies at different times were mostly inconsistent and erratic. The age-old feudal system had been practiced in the country until the collapse of the Imperial regime after a popular revolt in 1974. Feudalism is characterized by traditional social structure, where the critical means of production is land. Hence, agriculture was the engine of the country's economic development throughout the Imperial period. Socially, the feudal system was based on the production relations as well, dividing the society into two fundamental classes: the peasantry and the landlords $[18 ; 19]$. Accordingly, the social relations were based on exploitation, as the role of peasants was reduced to that of tenants, subordinated by landowners. The political system was also highly centralized under a despotic monarchy, which allocated land solely to those who kept their allegiance to the government and supported the autocratic regime. Naturally, there was no room for alternative political forces that could represent people's interests. Eventually, the politico-economic tensions led to the above mentioned popular uprising (involving peasants, drivers, teachers, soldiers, and students) in 1974, which resulted in toppling Emperor Haile Selassie and terminating the monarchical rule in Ethiopia. As Alemayehu notes [18], economic performance in Ethiopia parallels the political processes (and conflicts) that accompany it; hence, the Imperial regime's GDP growth averaged $4 \%$ in 1960-1974.

Following the uprising, the Military regime (Derg) acceded to power with a completely different ideology - socialism. Ethiopia became part of the Eastern bloc and switched from the feudal system to a command economic system, making the tillers' land public property. However, the period of this militaristic rule, later called "lost decades", was far from productive because of economic stagnation [20]. Between 1974-75 and 1989-90, the average GDP growth decelerated to $2.3 \%$ [18]. This slowdown was attributed to the economy's reliance on agriculture, which, in its turn is dependent on the vagaries of nature. Besides, the obligatory military service along with the institution of centralized planning and the nationalization of land, among other factors, contributed to the inability of agriculture to support the industry. Moreover, given the militaristic nature of the rule and the prevailing recurrent political turmoil, precedence was given to the defense industry and therefore capital investment was geared towards defense needs, which were mostly met by the Soviet Union and its allies [20]. Eventually, the regime was deposed, as its ideology was bringing neither economic nor political development, mainly because of the political setbacks.

After the failure of the centrally-planned command economic system and the fall of the Derg regime in 1991, the subsequent government, again, turned to the western liberal ideology [21;22]. After the cessation of the Cold War, which ended with a triumphant victory of the Western bloc led by the US, adopting a politico-economic model differing from the western standard was unreasonable, as lib- 
eral capitalism became the world's dominant ideology. According to Francis Fukuyama, this was the time that marked the end of man's ideological evolution [23]. Most importantly, it was the US that contributed immensely to bringing the Ethiopian People's Revolutionary Democratic Front (EPRDF) into power. Thus, to show its allegiance to US and have the privilege of western support in the course of consolidating its power, EPRDF had no choice but jump on the bandwagon and advocate liberal ideology. Without a doubt, subscribing to the western creed has helped the regime to shore up its position; however, the country has not been able to adjust the western beliefs to Ethiopian reality, and as a result, neither a true liberal electoral democracy nor economic development have been achieved.

After promulgating the free market economy for about ten years, the government officially declared the introduction of the developmental state model, explaining that the free market system cannot function in Ethiopian conditions without selective state intervention [22]. The conclusion was based on the fact that the country's economy was significantly limited and the factors of production were highly constrained, making it impossible for Ethiopia to compete in the global market unless the government gets involved in the process [24]. Consequently, the state has established control over the country's entire economy, playing the role of a guide and choosing not to make micro-scale investments. This change coincided with the rise of Asian countries with an alternative economic model, and eventually the country's exclusive dependence on the West has started to wane. The formal introduction of the idea of a developmental state in Ethiopia is, therefore, a relatively recent event. Concerns regarding whether a developmental state model is applicable in Ethiopia have taken center stage in the recent discussion among the nation's prominent researchers, politicians, and academics. The sections below examine the model's positive and negative effects (which possibly will continue in the future) on Ethiopian reality.

Highlighting the economic progress. One cannot argue that Ethiopia witnessed certain progress in a number of areas following the adoption of the developmental state model. This is especially true in regard to the country's economic performance. The introduction of the new model almost coincided with the formal launch of Sustainable Development and Poverty Reduction Program (SDPRP) in 2003, which focused on agriculture, education, and development of infrastructure [25]. The program boosted the GDP growth rate from $2.3 \%$ to $5.9 \%$, although it failed to do much about the poverty the majority of population was facing. Building on the positive achievements of the program in GDP, in 2005, Plan for Accelerated and Sustained Development to End Poverty (PASDEP) was launched. The plan put attention on urban development, which was overlooked in the previous program [25]. With this initiative, the country managed to achieve a noticeable economic growth (11\%) and reduce the poverty level.

Most importantly, the developmental state orientation has been buttressed with the Growth and Transformation Plan I and II. With the conviction that the increasing economic performance attained by the aforementioned programs could not be sustained without focusing on the manufacturing sector, in 2010-11, 
the government introduced the Growth and Transformation Plan I, which authorized the state to assume a key leadership role in economic planning [26]. Currently, Plan I has been completed and replaced by Plan II. The achievements of the programs are undeniable: the country is vigorously working on its industrial development, with numerous new industries growing like mushrooms. Two of the recent examples, among numerous other ongoing projects, are the Hawassa Industrial Park (a textile and apparel production base) and Bole Lemi Industrial Park (an industrial hub for export-oriented manufacturers), which have recently become operational $^{1}$. There is hope that these new industrial projects will help boost the country's economy and do away with the debilitating poverty. There is, however, also fear that in an attempt to reduce poverty these mega projects rely exclusively on trickle-down benefits of economic growth. The concern is that the benefits of these grand projects will not be enjoyed anytime soon and that they are mostly aimed at the distant future.

The aforementioned successive development initiatives, as part of the broader developmental state model, produced a persistently increasing economic development in the country $[27 ; 28]$. The percentage of growth rate varies from source to source. For instance, according to Clapham [27], by the year 2015, the country's GDP growth rate was 9.6\%, making it the highest in Africa and second highest in the world. Based on the World Bank's report, Ethiopia scored annual growth rates of $10.4 \%$ in $2015,7.6 \%$ in 2016 , and $10.2 \%$ in 2017 [29]. The report also asserts that the country achieved a remarkable economic growth averaging $10.3 \%$ a year from 2006-07 to 2016-17, compared to a regional average of 5.4\% [30]. According the UNDP sources, the real GDP growth in Ethiopia shot up from 8.0 percent in $2015-16$ (due to the drought) to 10.9 percent in $2016-17$ [31]. The industrial sector, especially its construction sub-sector, was the major contributor to the growth in 2016-17, as it took over the services sector, following the guidelines of the GTP I\&II and their focus on manufacturing. Despite the minor numeric variations, the country's economic progress has been acknowledged and confirmed by all authorities without hesitation. The soaring economic growth ranked Ethiopia among the world's fastest-growing economies in 2018 [32]. Furthermore, the share of population living below the national poverty line decreased from $30 \%$ in 2011 to $24 \%$ in 2016 [30] and dropped from $27 \%$ in 2016 to $24 \%$ in 2018 [32] by international poverty line standards. It is therefore undeniable that the introduction of the developmental state model has led to impressive changes in terms of economic growth and industrialization.

To stimulate and sustain the industrialization process in particular and economic transformation in general, the government has been paying special attention

\footnotetext{
${ }^{1}$ Follow the link. To see more on the additional projects in several parts of the country, such as Mekelle, Dire Dawa, Kombolcha, Adama. URL: http://www.investethiopia.gov.et/investmentopportunities/strategic-sectors/industry-zone-development.
} 
to infrastructural development, allocating a significant share of its national budget to infrastructural needs. The expansion of roads, railways, air transportation, national grid, and telecommunications is the evidence of the government's focus on organizational facilities. In this respect, admirable progress has been achieved, which is crucial in making the country more appealing for foreign investment.

The above mentioned unprecedented economic growth, however, comes with a price of certain downsides. There is a colossal gap between the rich and the poor, by far greater than in neighboring free market Kenya [33]. While some Ethiopians lead an exorbitantly rich lifestyle, their fellow countrymen find themselves stuck in the poverty quagmire. Since the economic growth could not significantly ameliorate the uneven distribution of wealth among various society groups, its viability remains rather questionable [34]. For instance, according to Oxford Poverty and Human Development Initiative [35], the percentage of the population living in severe poverty in Somali $(81.9 \%)$ is much higher than in Harari $(36.6 \%)$ and Dire Dawa (38.5\%). Similarly, the level of poverty reduction is not equal in urban and rural areas; the percentage of the rural population living in dire poverty is almost quadruple that of the impoverished urban population (82.1\% and $21.0 \%$ respectively) [32] also supports this assessment, observing that poverty reduction is more successful in urban areas than in the countryside. This difference can be attributed to the fact that the government (frequently accused of corruption and illicit financial flows) favors major cities over rural areas [36].

\section{Some detrimental effects}

Notwithstanding the undeniable economic progress, the way the developmental state model has been applied is hardly flawless. Although the Ethiopian government claims it has been pursuing a democratic model, so far, it has worked mainly on its economic aspect, sidelining the political transformation. As a matter of fact, the continuous economic growth has served as a criterion for successful administration, justifying political malpractices and legitimizing increasing authoritarian tendencies $[24 ; 37 ; 38]$. It is noteworthy that the developmental state model per se did not create the problem; however, the government's manipulation of the system's natural tendency to authoritarianism in an attempt to sustain power and reinforce control has significantly contributed to the system's malfunction. For a developmental state to function properly, a committed and civic-minded leadership, which Ethiopia is presently lacking, is a crucial condition. The democratic form of governance has remained but an aspiration for the citizens: simply put, Ethiopia is a democratic developmental state in name and an authoritarian developmental state in reality. Consequently, as a result of the developmental state model orientation, certain problems have occurred and possibly will continue to occur. Importantly, theses detrimental effects are not mutually exclusive; they are interrelated and reciprocally aggravating. 


\section{Eroding the value of pluralism}

For a better realization of the developmental state theory, a state needs to insulate itself from the demands of diverse social classes $[39 ; 11 ; 6 ; 3 ; 8 ; 41]$. This assertion is based on the conviction that conflicting interests of smaller social groups can detract from the capacity of a state to achieve a better overall economic performance [40; 39; 9]. Concurrently, Onis [2] asserts that the developmental state model is "inconsistent with the vision of a pluralistic form of democracy, in which a multitude of small-scale interest groups enjoy broadly equal and unrestricted access to the state." Therefore, according to some opinions, a developmental state neglects demands of smaller social groups that may divert it from its main developmental priority [2].

Ethiopia is a multi-ethnic country with various religious and cultural groups. Different, and in some cases conflicting, interests of these groups can be a potential bottleneck in implementing the developmental state model, as they impede the consensus required for its successful functioning. However, it is equally impossible to disregard the interests of these diverse groups. One is under the impression that in order to smooth over the cross-ethnic contradictions, the state intentionally added the attributive democratic to the developmental state model [22]. However, public disaffection regarding the distribution of power, resources, and social opportunities is hard to ignore [3]. As the government operates relying on the policies and agendas set by the ruling party, ignoring the interests of the diverse local communities and sans their approval, the discontent keeps growing. The problems and concerns of the locals remain discounted, while their knowledge and possible input are not being taken advantage of, even though a multi-national community, ipso facto, requires people's involvement in the country's affairs. The single leading political party makes decisions for the whole society as it deems it knows what is in the people's best interests. This situation contradicts the cardinal principle of pluralistic democracy which presupposes popular participation. Unfortunately, according to the assessment by Freedom House, Ethiopia has ranked lowest, scoring 0 out of 16 in 'political pluralism and participation', due to the exclusion of the public from any genuine and autonomous political participation [41]. The resulting political demonstrations which sprung up across the country were all quashed by government law enforcement agents. The country's leaders have turned a deaf ear to peoples' needs, ideas, and opinions deeming them to be obstacle in the government's way to ensuring economic development.

The government's neglect of people's interests can partly be contributed to the mixing of developmental state theory with the philosophy of democratic centralism, borrowed from Leninist ideology that forefronted a tightly disciplined and centrally organized vanguard party [10], as well as the ideas of revolutionary democracy that naturally allows for the political stage to be occupied by a number of politicians substituting the opinion of the majority [42]. On this account, Fantini [38] writes "development policies, targets and programs are designed at the centre, authorizing regional and local authorities little room for maneuver, in a cen- 
tralistic and top-down logic". Despite the formally decentralized federal structure, there has been "little recognition for local knowledge or the autonomous aspirations of groups and individuals", which compromises the value of pluralism in the country. Differently put, a small cluster at the top (the ruling party) makes "one size fits all" decisions for the heterogeneous Ethiopian society. It would therefore be naïve to expect pluralism to flourish in a society where a dominant ruling-party is strictly committed to democratic centralism [37].

It is the author's conviction is that if the state continues to insulate itself from local communities' needs and opinions just to achieve national developmental goals, the existing occasional discontent can intensify and further lead to severe inter-group conflicts and resentment in the country. This, in turn, dims a chance for peaceful coexistence and depreciates the value of pluralism propagated by the government. Therefore, the natural emphasis of a developmental state on economic performance, together with the weak commitment of the government of Ethiopia to pay due attention to local problems, can aggravate the existing dissatisfaction of the deeply divided "democratic" society. The inter-ethnic conflicts would, in their turn, backfire and impede the country's economic growth. Hence, the best possible effort should be made towards unifying the dissenting society and ensuring consensus-oriented governance.

\section{Jeopardizing human rights}

It is true that the developmental state model requires a strong interventionist state. However, this does not mean that the developmental state theory is compatible only with authoritarian states, as one can adduce the cases of Brazil, India, South Africa, Mauritius and Botswana, where democratization and developmental processes occur simultaneously [6]. However, in view of the developmental state's primary focus on economic development, repression of certain rights and freedoms is more than likely to happen. In this respect, Bolesta [4] comments that "it seems justifiable to claim that a developmental state would be difficult to sustain in a fully democratic system in which people enjoy extensive rights". Consequently, a developmental state can be practiced only at the cost of compromising human rights.

Ethiopia has an abysmal human rights violation record over the past few successive regimes, in spite of the country's commitment to abide by various national, regional and international human rights and freedoms [43]. The current regime (EPRDF) is notorious for extensive abuse of human rights, especially civil and political rights. It is evident that the regime's adherence to the developmental state model has served as a cover for further violation of the rights of citizens. While giving priority to economic development, Meles Zenawi, the late prime minister of Ethiopia and the mastermind behind the introduction of the model in the country, plainly asserted that "development and a strong state were prerequisites for human rights, and Ethiopia needed to establish these first" [44]. He boldly and implicitly stated that "We must have growth, growth, growth... we can't have 
democracy with an empty belly" [24]. As can be inferred from this argument, it is acceptable to neglect democracy in general and human rights in particular to achieve a necessary degree of economic development and state strength. Some even question applicability of the model in the country, suspecting Ethiopia of following the eastern way because of its disinterest in respecting human rights and abiding by democratic principles [22].

The bottom-line is that economic development has been used, and will potentially continue to be used, as a legitimate excuse for violation of people's rights. This issue may become a matter of concern for the global community, which continues to keep track of domestic human rights infringement records [34]. It is the author's conviction that economic growth and human rights should be pursued simultaneously, and not in succession, as was articulated by Meles; the freedoms of citizens must not be suppressed under the cover of economic growth. What is more important, growth achieved at the expense of human freedoms is not going to be sustainable as it leads to instability and inevitably stirs up public discontent. The recent political unrest and people's protests prove the author's assumption. Human rights are not to be "thrown under the bus" of the top priority of economic growth, but they are equally vital for the country's overall development.

\section{Entrenching a single party authoritarian rule}

Though the developmental state model has been adopted in both democratic and undemocratic states, numerous scholars observe that in a democratic political environment its efficiency is challenged $[3 ; 4 ; 6 ; 13]$. This assumption is based on the crux of democracy, which seeks to decentralize power and make the state less autonomous and more geared towards societal demands [6]. This nature of democracy is inconsistent with the requisites of a developmental state, as the latter gives priority to economic development over political reform. Therefore, advancing the democratization process in a developmental state is a rather challenging task: such states pursue the establishment of a strong and stable government that muffles any undertakings contradicting their developmental goals, justifying and legitimizing their actions on account of developmental achievements and ignoring people's interests $[4 ; 9]$. Various scholars call attention to the tendency of a developmental state to become authoritarian and to fear the replication of the East Asian state model in other regions [3].

Ethiopia's fragile democracy is yet more proof that a developmental state has a tendency to become authoritarian. The country's political administration is characterized by a highly centralized single-party rule (EPRDF). The EPRDFdominated Ethiopian government is in its turn controlled by the Tigray People's Liberation Front (TPLF) [45]. There are opinions that the raison d'être of the developmental state in Ethiopia is to ensure the continued authoritarian single-party dominance [15]. This argument is reasonable in the light of Meles Zenawi's assertion about the importance, inter alia, of maintaining the government's policy for an extended period of time to guarantee the success of the developmental state 
model [44]. This idea contradicts the essence of electoral democracy, which is characterized by frequent government changes and, at times, discontinuity of policy [21]. Moreover, Meles even declared that 'there is no reason to believe that democratization is a precondition of economic development' [34] and alluded to economic developments under dictatorships [28].

The actual state of things is in congruence with these ideas, and the rulingparty has an iron grip on political power. With the entire political space and state authority being completely controlled by the EPRDF, the country is undergoing a democratic deficit. The government has further expanded its control and entrenched its dictatorship, in particular after the historic election in 2005, when it took off the scene anything that represented a possible challenge: opposition parties, civil society organizations and the media. The late prime minister expressed his negative stance on all these "agents of democratization", fearing that they could "easily become patronage mechanisms" in the Ethiopian context [34]. Meles took measures to achieve their complete elimination and thus warranted the ruling-party's political hegemony. All successive elections, as well as the multiparty system in Ethiopia, are but democratic camouflages used to consolidate the ruling-party's inclusive authority.

In this context, certain authorities remarked that Ethiopia is following an 'authoritarian developmental state' model [46] and labeled the Ethiopian system of governance "developmental authoritarianism", i.e. a public administration system where the state leadership controls virtually every aspect of the society [47]. Ethiopians have been forced to live in the conditions of heavy-handed single-party authoritarianism, which has been covering up the leading party's strive for absolute power under the pretext of effective realization of the developmental state model.

\section{Rampant corruption as a consequence}

The developmental state model is vulnerable in terms of its susceptibility to corruption, although the flaw exists in other ideological models as well. Unless the model is correctly implemented, the state's intervention in the economy can pave a way for misuse of state power and embezzlement of public assets. Some experts remark that "in the process of enriching the nation, the state might prefer to enrich itself and not the people" [4]. The close relationship between economic bureaucrats and the business sector can lead to collusion or monopoly, as it has been witnessed in a series of corruption scandals in Japan and South Korea [7].

It is also worth mentioning that adopting and enforcing a developmental state model in an already corrupted bureaucratic system is quite reckless. According to some opinions in the UN, "African states are too corrupt and predatory, and ruled by rent-seeking or just plain kleptocratic officials who prioritize their private interests over those of the state, and use rents to fund patronage for their constituents" [9]. Ethiopia is no exception, as corruption prevails in different development sectors. The author believes that the country's adherence to the developmental state model has aggravated the existing problem by giving officials a better oppor- 
tunity for exploiting the core economic sectors. The facts on the ground serve as a proof: for example, the recently spotlighted scandals in Sugar Corporation, Grand Ethiopian Renaissance Dam, Ethiopian Shipping and Logistics Services Enterprise, Ethiopian Civil Aviation, Yayu Fertilizer Factory [48], among others, demonstrate the degree of corruption of the key economic sectors by top government officials. Those in power have been taking advantage of their interventionist role and familiarity with the business sector and massively capitalized on the country's resources, while the majority of Ethiopians have been living below poverty line. Meanwhile, the government is looking for humanitarian aid and loans from overseas.

The developmental state system requires a true patriotic, determined, and insightful leader; however, in reality the system remains corrupt though and through, while the actual leadership, greedy for gain, uses it as a cover for its selfish interests. Corruption has established a strong foothold in the Ethiopian political system and developed as an independent structure with a clear chain of interaction among officials at various levels of the government. During his speech on the national anticorruption day, the current prime minister referred to the corruption scheme as to 'the fifth government', alluding to it immense power and influence.

The Ethiopian government cleared all potential obstacles (the media, civil society organizations, opposition groups, and activists) on its way to absolute power, which created a fertile environment for kleptocracy. If the eliminated groups were present and active, they could hold government officials accountable by exposing their wrongdoings; however, currently the government is the only game in town in the Ethiopian political environment [43].

Corruption not only creates unjustifiable income inequality among citizens, but also causes conflicts and instability that, in a never-ending circle, produce a breeding ground for corruption. One can witness this "catch-22" situation in Somalia, Syria, South Sudan and Yemen, which experience perpetual political turmoil and are notoriously the most corrupted countries in the world [49]. The problems discussed in this paper, namely depreciation of pluralism, egregious violation of human rights, pervasive single-party authoritarianism, and arbitrary intervention in the lives of citizens are all potential causes of violence and instability, as well as a hotbed for corrupt practices. All these negative repercussions considered, the improper application of the developmental state model puts the country in a vicious cycle of bad governance.

Recently, efforts have been made to arrest suspected criminals. As a result, certain senior officials are now leaving office, as they have been discredited for corruption, bankruptcy and advancing outside interests [24]. Nevertheless, whether the new office holders are truly committed to represent national interests and capable to resist corruption still remains to be seen. At the same time, effective anti-corruption legal and institutional mechanisms have not yet been firmly established. 


\section{Intensifying arbitrary intervention}

State intervention in the country's economy is a core feature of the developmental state model. However, the intervention should be done selectively, in a way that facilitates the overall economic performance of a state. In case with Ethiopia, however, the intervention of the state has been unlimited, to the extent of making the country "market unfriendly" [15]. The state's arbitrary and unrestricted interference in the economy has resulted in such negative developments as inflation and shortage of access to some basic commodities, which contradicts the principle of capitalist economic environment within the developmental state model [4].

It appears that land ownership in Ethiopia has been affected by state intervention in the most detrimental way. Land for Ethiopians is an object of strong sentimental attachment, as it has been the crucial source of livelihood for centuries. The 1995 FDRE constitution explicitly confers the ownership of urban and rural land to the state and its people (Art. 40). At the same time, it authorizes the state to displace citizens from their settled lands when it is for the purpose of development or public interest, as long as a commensurate compensation is provided (Art. 44). In the great scheme of things, several development programs were carried out by the interventionist state completely within a legal framework, at times with some serious consequences for citizens. The government displaced families, oftentimes liberally and extensively interpreting public interest. The displacements in Gambella and other southern parts of the country as part of the Integrated Master Plan (IMP) for enlarging the capital city into the Oromo region can serve as a vivid example of such underhanded actions by the government [47]. The situation worsens in Addis Ababa, where large numbers of people are being displaced from the center to the suburbs in the name of public interest. According to multiple complaints, neither the displaced families get enough compensation to resume their lives at the new location, nor are the government projects fully implemented to serve public interests.

Such state of affairs creates resentment, conflict and instability. In addition, the authority of the government to relocate citizens at its will inevitably discourages people from participating in any productive developmental projects [15]. The author finds it unreasonable to suggest that the government refrains from uprooting people altogether but insists that "public interest" must not be construed broadly to serve vested interests and the displaced should get adequate compensation. He further contends that people's relocation should only be allowed if it benefits the people and not because it serves the developmental state's objectives. The author is convinced that the government abuses its interventionist role and wrongly applies the developmental state model, which aggravates existing social problems.

\section{Recent changes: Too little too early}

After Abiy Ahmed's recent ascendency to prime minister, certain progress in Ethiopian federalism-based system has been achieved. Within less than a year, the 
new government has been able to encourage optimism in people. It has started disestablishing some long-standing political structures, programs, and institutions that were ineffective and dictatorial, while striving to liberalize the political space for various competing forces. Exiled opposition political parties were invited to come back, and almost all are now operating domestically side-by-side with the ruling party, which used to be the only option. The political horizon has also opened up for the media: they are enjoying more freedom these days, giving publicity to several political issues, including ones that challenge the government, which was impossible under the former administration. Moreover, the government is revising the Charities and Societies proclamation that has for long kept civil society organizations away from political activities, especially after the 2005 election.

The new prime minister has also launched a number of institutional reforms in different spheres, including security, which are targeted at improving the government's legitimacy. Furthermore, the new office has started to place a greater focus on people's interests and concerns, which had been disregarded by the previous administration, effectively discrediting the government. Abiy began his office by conducting a public discussion in several parts of the country, allowing people to voice their most pressing issues. As Melisew and Cochrane [34] note, the incumbent prime minister has made a good start with his reforms and set the stage for the correct implementation of the developmental state model.

In addition, the government is working on bringing human rights transgressors to justice in the courts of law. Several top government officials have already been summoned to appear before court in regards to grave corruption scandals. It is obvious that the new administration has entered an active struggle against corruption.

Despite the obvious positive changes, the Ethiopian government is still faced with various challenges. One of the major challenges these days is that the government lacks internal coherence, as the parties constituting the ruling coalition have no common understanding of the ongoing reforms, future programs and visions of the development. There has been certain fissures between the coalition's former preponderant component, the Tigray People's Liberation Front (TPLF) and the rest of the members. Dissatisfied with the reforms, TPLF is operating virtually independently and, as a way of opposing the actions taken by the new leadership, it has shielded a number of indictable top officials who were involved in corruption scandals and human rights violations. By the look of things, the government is not exercising effective control over the entire territory of the state. On top of all, the coalition fragmentation has led to an internal political power shift, stripping the government of their monopoly on the legitimate use of force and thus facilitating a spiral of ethnically motivated violence in various parts of the country [50]. To complicate the matter, some opposition factions that recently reentered the country, are also conflicting with the government and igniting the increasing ethnic unrest. As a consequence, the country's long-standing problems have been exacerbated by more lawlessness, insecurity, and distrust. 
As far the country's possible transition to democracy is concerned, there are still ambivalent sentiments. As was eloquently put by Solomon, Ethiopia is experiencing a 'spring of hope and winter of despair' [51]. Despite the reforms that have been launched, it is difficult to assure that the changes brought by the new administration will continue and bring the long-awaited genuine political change in the country. In the same respect, there are even further concerns that the new leadership will use the media for propaganda in regards to its outlook on the current issues without previously establishing and putting to practice new solid institutional tools. Besides, some of the recent changes have created discontent and resentment on the part of certain ethnic groups.

Moreover, there is still a reasonable doubt that the country's former authoritarian way of governance may prove to have a lingering effect. Currently, with the country being at transitional crossroads, it is difficult to arrive at a clear-cut conclusion about the real benefits of the aforementioned progress made by the new government. The changes witnessed so far are not enough to make a definite optimistic prediction about the future of the political system of the country in general and the developmental state model in particular. Furthermore, it is uncertain whether Abiy will continue to implement the federalism-based system or give up on it in the future. The prime minister did not make any public comment in regards to his intention to proceed with the developmental state orientation of the country, being more concerned about the spiraling political turmoil in the country.

\section{Conclusion}

After decades of rule based on the western liberal model, the new Ethiopian government has adopted the concept of a developmental state within the federalismbased political system. Following the rise of an alternative politico-economic model in the East, the government resorted to the aforementioned system, believing that the western free market economy cannot function in Ethiopian reality without a selective state intervention. The developmental state model has brought an exponential economic growth, which has been attested to by various researchers and international multilateral financial institutions. However, the political aspect of a developmental state has not received equal attention. The government has used the increasing economic growth as a criterion for administrative decisions and thus prioritized economic advancement and put democratic development on the back burner. The natural drift of the model towards authoritarianism coupled with the inherent interest of the ruling-party to sustain its power and strengthen control caused an improper application of the model and plagued the country with growing autocracy. Very recently, following the appointment of the new prime minister, certain important political changes have been made; however, it is too early to make any conclusions about whether the government is properly applying the model or if the country is entering into a genuine democratization process. 


\section{References}

[1] Chang D. Capitalist Development in Korea: Labour, Capital and the Myth of the Developmental State. London: Routledge; 2009. 216 p.

[2] Öniş Z. The Logic of the Developmental State. Comparative Politics. 1991; 24 (1): 109-126.

[3] Sehen B., Tsegaye R. Democratization in a Developmental State: The Case of Ethiopia, Issues, Challenges, and Prospects. UNDP Ethiopia. 2012; 1. 24 p.

[4] Bolesta A. China as a Developmental State. Montenegrin Journal of Economics. 2007; 5: 105-111.

[5] Johnson C. MITI and the Japanese Miracle: The Growth of Industry Policy, 1925-1975. California: Stanford University Press; 1982. 412 p.

[6] Fritz V., Menocal A.R. Developmental States in the New Millennium: Concepts and Challenges for a New Aid Agenda. Development Policy Review. 2007; 25 (5): 531-552.

[7] Kim W. Rethinking Colonialism and the Origins of the Developmental State in East Asia. Journal of Contemporary Asia. 2009; 39 (3): 382-399.

[8] Boyd R., Ngo T.-W. Emancipating the Political Economy of Asia from the Growth Paradigm. Asian States: Beyond the Developmental Perspective. Boyd R., Ngo T.W. (eds). New York: Routledge Curzon; 2005: 11-18.

[9] Economic Development in Africa: Reclaiming Policy Space: Domestic Resource Mobilization and Developmental States. United Nations: New York and Geneva; 2007. 122 p. DOI: 10.18356/fcb9b895-en.

[10] Heywood A. Politics, fourth edition. UK: Palgrave Macmillan; 2013. 496 p.

[11] Kim W. Rethinking Colonialism and the Origins of the Developmental State in East Asia. Journal of Contemporary Asia. 2009; 39 (3): 382-399.

[12] Asayehgn D. The Continuing Saga of Globalism: Comparing Ethiopia's Developmental State Strategies to those of Malaysia. International Journal of Management Sciences and Business Research. 2012; 1 (11): 87-103.

[13] Haggard S. Developmental States: Elements in the Politics of Development. UK: Cambridge University Press; 2018. 120 p. DOI: 10.1017/9781108552738.

[14] Edigheji O. Constructing a Democratic Developmental State in South Africa: Potentials and Challenges. South Africa: Human Sciences Research Council; 2010. 336 p.

[15] Ayenachew A. Indicia of the Developmental State Concept in the Ethiopian Higher Education. Unpublished MA Thesis, University of Tampere, Finland; 2014.

[16] Mesgna G. The Challenges and Prospects of Building a Developmental State in Africa: A Comparative Study of Botswana and Ethiopia. Unpublished MA Thesis, Addis Ababa University, Addis Ababa; 2015.

[17] Creswell J. Research Design: Qualitative, Quantitative, and Mixed Methods Approaches, 2nd ed. Thousand Oaks: Sage Publications, Inc; 2003. 26 p.

[18] Addis H. From Autocracy to Bourgeois Dictatorship. Review of African Political Economy. 1975; 1: 1-94.

[19] Alemayehu G. The Political Economy of Growth in Ethiopia. The Political Economy of Economic Growth in Africa, 1960-2000. Ed. by B. Ndulu, S. O'Connell, R. Bates, P. Collier, Ch. Soludo. Cambridge University Press: Cambridge African Economic History Series; 2007: 348-390. DOI: 10.1017/CBO9780511492648.011.

[20] Oqubay A. Industrial Policy and Late Industrialization in Ethiopia. African Development Bank Working Paper Series $N^{\circ}$ 303. Abidjan, Côte d'Ivoire; 2018. 26 p.

[21] Tsehai A. The Ethiopian Developmental State: Requirements and Perquisites. Journal of Business \& Economics Research. 2009; 7 (8): 11-18. 
[22] Müller F. Model Transfer in the Making: Changing Development Strategies and Expectations Towards the State in Ethiopia and Ghana. Working Papers Series. 2015; 15.

[23] Fukuyama F. The End of History? The National Interest. 1989; 16: 3-18.

[24] De Waal A. The Future of Ethiopia: Developmental State or Political Marketplace? World Peace Foundation. 20.08.2018. 19 p.

[25] Understanding African Experiences in Formulating and Implementing Plans for Emergence: A Case Study of Growing Manufacturing Industry in Ethiopia. UNDP. 2017. 50 p.

[26] Planel S., Bridonneau M. Glocal Ethiopia: Scales and Power Shifts. EchoGéo. 2015; 31: 119. DOI : 10.4000/echogeo.14219.

[27] Clapham Ch. The Ethiopian Developmental State. Third World Quarterly. 2017; 39 (6): 1151-1165.

[28] Fesseha M., Abtewold M. Ethiopia: A Democratic Developmental State? ILIRIA International Review. 2017; 7 (2): 9-26.

[29] Ethiopia, GDP Growth (Annual \%). World Bank. 2018. Available from: https://data.worldbank.org/indicator/NY.GDP.MKTP.KD.ZG?locations=ET\&year_high_des $\mathrm{c}=$ true. Accessed: 10.02 .2019 .

[30] Ethiopia: Overview. World Bank. 2018b. Available from: https://www.worldbank.org/en/ country/ethiopia/overview. Accessed: 10.02.2019.

[31] Quarterly Economic Brief: United Nations Development Programme Ethiopia. UNDP. 2018; I. Available from: http:/www.et.undp.org/content/dam/ethiopia/docs/Quarterly\%20Economic\% 20brief\%201st\%20quarter\%202018.pdf. Accessed: 10.02.2019.

[32] Ethiopia: Recent Developments. World Bank. 2018. Available from: http://pubdocs.worldbank.org/en/471041492188157207/mpo-eth.pdf. Accessed: 10.02.2019.

[33] Jay S. Opinion: One More Question, Dr. Abiy. Addis Standard. 15.09.2019. Available from: https://addisstandard.com/opinion-one-more-question-dr-abiy/. Accessed: 16.02.2019.

[34] Melisew D., Cochrane L. Ethiopia's Developmental State: A Building Stability Framework Assessment. Development Policy Review. 2019; 37 (2): 161-178. DOI: 10.1111/dpr.12414. DOI: $10.1111 /$ dpr.12414.

[35] OPHI Country Briefing 2017: Ethiopia. Oxford Poverty and Human Development Initiative. Oxford: University of Oxford; 2017.

[36] East Africa and the Horn in 2022: An Outlook for Strategic Positioning in the Region. InterAgency Research and Analysis Network (IRIS). 2017.

[37] Gebremariam E. The Carrot and Stick of Ethiopian 'Democratic Developmentalism': Ideological, Legal and Policy Frameworks. The Democratic Developmental State: North-South Perspectives. Stuttgart: ibidem-Verlag / ibidem Press; 2018: 61-86.

[38] Fantini E. Developmental State, Economic Transformation and Social Diversification in Ethiopia. ISPI Analysis No. 163. Milan: ISPI; 2013.

[39] Minns J. The Politics of Developmentalism: The Midas States of Mexico, South Korea and Taiwan. New York: Palgrave Macmillan; 2006. 310 p. DOI: 10.1057/9780230625563.

[40] Mkandawire T. Thinking about Developmental States in Africa. Cambridge Journal of Economics. 2001; 25: 289-313.

[41] Freedom in the World 2018: Ethiopia Profile. Freedom House. Available from: https://freedomhouse.org/report/freedom-world/2018/ethiopia. Accessed: 10.02.2019.

[42] Lefort R. Free Market Economy, 'Developmental State' and Party-State Hegemony in Ethiopia: The Case of the 'Model Farmers'. Journal of Modern African Studies. 2012; 50 (4): 681-706.

[43] Bayeh E. Incorporation of Human Rights into Legal Frameworks of the three Successive Regimes of Ethiopia and their Treatment: A Comparative Analysis. European Journal of Humanities and Social Sciences. 2014; 32 (1): 1736-1751. 
[44] De Waal A. The Theory and Practice of Meles Zenawi. African Affairs. 2012; 112/446: 148-155.

[45] Clapham Ch. Ethiopian Development: The Politics of Emulation. Commonwealth \& Comparative Politics. 2006; 44 (1): 108-118.

[46] Thakur M. Building on Progress? Chinese Engagement in Ethiopia. SAIIA Occasional Paper. 2009; 38.

[47] Matfess H. Rwanda and Ethiopia: Developmental Authoritarianism and the New Politics of African Strong Men. African Studies Review. 2015; 58 (2): 181-204.

[48] Metec corruption exposed "documentary". Fana TV. 2018. Available from: https://www.youtube.com/watch?v=NRre1adxyCU\&t=6s. Accessed: 10.02.2019.

[49] Corruption Perceptions Index 2018. Transparency International. 2018. Available from: https://www.transparency.org/cpi2018. Accessed: 10.02.2019.

[50] Woldemariam M. Can Ethiopia's Reforms Succeed? What Abiy's Plans Mean for the Country and the Region. Foreign Affairs Magazine. 10.09.2018. Available from: https://www.foreignaffairs.com/articles/east-africa/2018-09-10/can-ethiopias-reformssucceed. Accessed: 10.02.2019.

[51] Solomon D. Ethiopia's Spring of Hope and Winter of Despair. solomondersso.wordpress.com. 07.08.2018. Available from: https://solomondersso.wordpress.com/2018/08/07/ethiopias-spring-ofhope-and-winter-of-despair/. Accessed: 10.02.2019.

Article history:

The article was submitted on 20.02.2019.

The article was accepted on 07.11.2019.

\title{
Государство развития в Эфиопии: размышления об издержках рассмотрения экономического роста в качестве критерия государственного управления
}

\author{
Э. Байе \\ Университет Амбо \\ 19, Амбо, Эфиопия
}

Аннотация. В статье рассматриваются достижения и потери эфиопского государства после внедрения модели государства развития. В своем исследовании автор опирается в основном на вторичные источники, на основе тщательного анализа которых он делает следующий вывод: несмотря на то что модель развивающего государства привела к заметному экономическому росту и сделала Эфиопию одной из самых быстрорастущих экономик в мире, она также вызвала ряд пагубных последствий, включая подрыв ценности плюрализма, ущемление прав человека и укрепление однопартийного авторитарного правления, что привело к разгулу коррупции и усилению произвольного вмешательства в жизнь граждан. Автор полагает, что экономический рост и политические преобразования (демократизация) должны оцениваться одинаково и осуществляться параллельно, что требует подлинно патриотического, решительного и ориентированного на общество политического лидера.

Ключевые слова: государство развития, авторитарное правление, Эфиопия, экономический рост. 


\section{История статьи:}

Статья поступила в редакцию 20.02.2019.

Статья принята к публикации 07.11.2019.

\section{Информация об авторе:}

Эндалкашью Байе - преподаватель департамента гражданственности и этических исследований Университета Амбо (Эфиопия) (ORCID ID: 0000-0003-4404-4737) (е-mail: endbayeh@gmail.com).

\section{Information about the author:}

Endalcachew Bayeh - Senior Lecturer of the Department of Civics and Ethical Studies, College of Social Sciences and Humanities, Ambo University (Ethiopia) (ORCID ID: 0000-0003-4404-4737) (e-mail: endbayeh@gmail.com).

\section{Для цитирования:}

Bayeh E. Developmental State of Ethiopia: Reflections on the Costs of Viewing Economic Growth as a Governance Criterion // Вестник Российского университета дружбы народов. Серия: Политология. 2019. Т. 21. № 4. С. 642-660. DOI: 10.22363/2313-1438-2019-21-4-642-660

\section{For citation:}

Bayeh E. Developmental State of Ethiopia: Reflections on the Costs of Viewing Economic Growth as a Governance Criterion. RUDN Journal of Political Science. 2019; 21 (4): 642-660. DOI: 10.22363/2313-1438-2019-21-4-642-660 